\title{
Okul Çağı Çocukların Göz Sağlığında Etkili Faktörler: Sistematik Derleme
}

\author{
Myopia in School Age Children and Related Factors: A Sistematic Review
}

\section{Nükhet KIRA $\breve{G}^{1}$}

\section{ÖZ}

Bu gözden geçirme, okul çağı çocuklarının miyop görme problemi ve bununla ilişkili faktörleri incelemeyi amaçlamaktadır.

Çocuk göz sağlığına ilişkin yapılmış çalışmaları belirlemek için Pubmed, Scopus, Wiley Blackwell ve Cochrane veri tabanları kullanılmıştır. Tarama İngilizce dilinde 5 anahtar sözcük kullanılarak gerçekleştirilmiş̧ir. Tarama sonucunda araştırma kapsamına 14 çalışma alınmıştır.

Miyop göz sorununun gelişiminde ve ilerlemesinde ailesel öykü, cinsiyet, açık hava aktivitesi, yakın çalışma davranışlarının etkili olduğu görülmüştür. İncelenen çalışmalarda okul çağı çocuklarının göz sağlığını etkileyen faktörlerin benzer olduğu dikkati çekmiş̧ir. Ülkemizde konuya ilişkin araştırmaların ve eğitimlerin yapılması önerilir.

Anahtar Sözcükler: Çocuk, Göz, Miyop.

\section{ABSTRACT}

This review aims to investigate the myopic vision problem of school-age children and related factors. Pubmed, Scopus, Wiley Blackwell and Cochrane databases were used to determine the studies on pediatric eye health.

The search was conducted using 5 key words in the English language. As a result of the screening, 14 studies were included in the research.

Familial history, gender, outdoor activity and close working behaviors were effective in the development and progression of myopic eye problems. In the studies examined, it was observed that the factors affecting the eye health of school age children were similar. In our country, researches and trainings are recommended.

Keywords: Child, Eye, Myopia.

${ }^{1}$ Dr. Öğr. Üyesi, Halk Sağlığı Hemşireliği Uzmanı, Aydın Adnan Menderes Üniversitesi Hemşirelik Fakültesi Halk Sağlığı Hemşireliği Ana Bilim Dalı, nukhetkirag@gmail.com, ORCID: 0000000182232996

\begin{tabular}{llll}
\hline İletișim / Corresponding Author: & Nükhet KIRAĞ & Geliş Tarihi / Received: & 22.03 .2019 \\
e-posta/e-mail: & nukhetkirag@gmail.com & Kabul Tarihi/Accepted: & 16.12 .2019 \\
\hline \hline
\end{tabular}




\section{GİRIŞ}

Dünya'da yaklaşık 285 milyon insan görme engellidir. Bunların 39 milyonu kör ve 246 milyonu ise düşük görme derecesine sahiptir. Görme engelli bireylerin yaklaşık \%90'1 gelişmekte olan ülkelerde yaşamını sürdürmektedir. Küresel olarak düzeltilmemiş kırma kusurları görme bozukluklarının başlıca nedenidir. ${ }^{1}$

Dünya Sağlık Örgütü'ne göre dünyada 5-15 yaş arası 12,8 milyon çocukta düzeltilmemiş kırma kusuru bulunmaktadır. ${ }^{2,3}$ Dünya Sağlık Asamblesi evrensel göz sağlığ1 erişimi için 2014-19 eylem planını onaylamıştır. $\mathrm{Bu}$ plan kapsamında 2019 yılına kadar görme engelliliğinin $\quad \% 25 \quad$ azaltılması hedeflenmektedir. ${ }^{1}$

Ülkemizde yapılan bir çalışmada, çocukluk çağı körlüklerinin \%69,6 oranında önlenebilir olduğu bildirilmiştir. ${ }^{4}$ Okul öncesi ve okul dönemi dikkate alındığında ülkemizde ambliyopi riski bulunan grubun $\% 1,3$ ile \%6,5 arasında değiştiği; kırma kusuru oranının da \%10 civarında olduğu bildirilmektedir. $^{5-8}$

Yakın çalışma maymunlar üzerinde yapılan hayvansal çalışmalarda ve epidemiyolojik çalışmalarda en sık karşılaşılan çevresel faktördür. ${ }^{9-13}$ Göz sağlığ1 üzerinde yaş, cinsiyet, sosyoekonomik düzey, eğitim düzeyi, genetik faktörler, kitap okuma alışkanlıkları, sigara dumanına maruziyet, 1rksal özelikler gibi faktörlerin etkili olduğu görülmektedir.

$\mathrm{Bu}$ gözden geçirme okul çağı çocuklarının miyop görme problemi ve bununla ilişkili faktörleri incelemeyi amaçlamaktadır.

\section{Literatür Taraması}

Literatür taraması kapsadığ 1 yıllar açısından herhangi bir sınırlama yapılmaksızın, PUBMED, SCOPUS, WIILEY BLACKWELL ve COCHRANE veri tabanlarında yapılmıştır. Tarama İngilizce dilinde, 5 anahtar kelime kullanılarak gerçekleştirilmiştir. Taramada "children eye health", "children vision problem", "children and myopia", "eye health risk factors", "outdoor activity and myopia" anahtar sözcükleri kullanılmıştır.

Araştırmaya dahil edilme kriterleri; Araştırma popülasyonunun çocuklar olması, makalenin tam metnine ulaşılabiliyor olması, miyop görme problemi ve ilişkili faktörler konusunda olması esas alınmıştır.

Araştırmaya dahil edilmeme kriterleri; Araştırma popülasyonunun erişkinler olmas1, makalenin tam metnine ulaş1lamaması, miyop görme problemi ve ilişkili faktörler konusunda olmamasıdır.

\section{YÖNTEM}

İncelenen araştırmalardan konuyla ilgili çocuk gruplar üzerinde yapılan çalışmalardan tam metnine ulaşılabilenler dahil edilmiştir. Tarama sonucunda toplam 26748 (Pubmed:26085, Scopus:434, Wiley Blackwell:222, Cochrane:7) araştırmaya ulaşı1mıştır. Ulaşılan çalışmalardan 20640'1 çalışma konusuyla ilgisi olmaması sebebiyle derlemeye dahil edilmemiştir.

Geriye kalan çalışmalar tam metne ulaşılabilme ve araştırmaya dahil edilme kriterleri yönünden incelendiğinde uygun olan 26 araştırmaya ulaşılmıştır. Dört veri tabanından elde edilen 14 çalışmanın incelenen veri tabanlarında aynı olduğu belirlenmiştir. Araştırma kapsamına 12 çalışma dahil edilmiştir.

\section{Araştırmanın Sınırlılıkları}

$\mathrm{Bu}$ konuya ilişkin literatürde ulaşılan çalışma sayısının az olması çalışmanın sınırlılığıdır. 


\section{BULGULAR VE TARTIŞMA}

Çalışmalar 2006 ve 2018 yılları arasında yapılmıştır. Değerlendirilen araştırmaların örneklemini okul çăg çocukları oluşturmaktadır. Değerlendirilen araştırmaların örneklem sayıları incelendiğinde, Lim ve ark.(2014)'nın yaptı̆̆ çalışmanın örneklem sayısı en fazla $(n=15,316)$ olan çalışmadır. ${ }^{14}$ Dharani ve arkadaşları (2012) tarafindan yapılan çalışmanın örneklem sayısı en az $(n=117)$ olan çalışmadır. ${ }^{15}$ Miyop sorunu olmayan çocukların annelerinin yaklaşık \%48'i miyop tanısına sahipken, miyop sorunu olan çocukların annelerinde bu oran \%69 olarak belirlenmiştir. Benzer şekilde miyop sorunu olmayan çocukların babalarının \%44'ü miyop tanısina sahip, miyop sorununa sahip çocukların babalarının \%64'ü miyop sorunu yaşamakta olduğu saptanmıştır (Tablo 1). Anne ve babanın miyop sorununa ilişkin sağlık öyküsü çocukların miyop sorunu yaşaması üzerinde etkili faktör olarak görülmüștür. Miyop sorunu yaşayan ebeveyn sayısı da miyop üzerinde etkili faktörlerden biri olarak belirlenmiştir. Buna göre hiçbir ebeveyninde miyop sorunu olmayan çocukların gelecekte \%21'i miyop için riskliyken her iki ebeveyninde miyop sorunu olan çocuklarda bu risk $\% 45$ olarak belirgin bir artış göstermektedir. ${ }^{16}$ Miyop sorununun ilerlemesinde ailesel olarak miyop sorunu öyküsüne sahip olanlarda miyop sorununun ilerleyişi daha hızlı olmuştur (p:0,022). ${ }^{17}$ Guo ve ark.(2013) yaptığı çalışmada annenin miyop öyküsüne sahip olmasının çocuğun axial uzunluğu üzerinde etkili olduğunu belirlemiştir $\quad(\mathrm{p}: 0,02){ }^{18} \quad$ Ebeveynlerinde miyop öyküsü bulunmayan çocuklarda miyop $\% 8,7$ oranında görülürken her iki ebeveyninde miyop sorunu olan çocuklarda \% $\% 3,2$ oranında miyop görüldüğ̈̈ saptanmıştır. ${ }^{8}$ (Tablo 1). Annenin miyop sorununa sahip olması çocukların gelecekte miyop sorunu yaşamasında $\% 24$ oranında etkili babanın miyop sorununa sahip olmasının çocuğun göz problemi yaşamasında $\% 25$ oranında etkili faktörler olduğu saptanmıştır. ${ }^{19} \mathrm{Wu}$ ve ark.(2013) yaptıkları çalışmada ailesel miyop öyküsünün çocuğun miyop sorunu yaşaması üzerinde etkili olmadığını belirtmiştir. ${ }^{20}$ Ip ve ark.(2008) yaptıkları çalışmada en az bir ebeveyninde miyop göz sorunu olan çocukların ebeveynlerinde miyop problemi olmayanlara göre anlamlı düzeyde miyop görülme sıklığının daha fazla olduğunu belirlemişlerdir $(\mathrm{Cl}: 1,9-3,8) .{ }^{21}$ Ebeveynlerinin en az birinde ve her ikisinde miyop sorunu olan çocukların ebeveynlerinde miyop sorunu olmayan çocuklara göre daha fazla bu göz sorununu yaşadıklarını saptamıştır. ${ }^{22}$ Hindistan'da yürütülmüş araştırmanın sonuçlarına göre aile öyküsünde miyop olan çocuklarda aile öyküsü bulunmayan çocuklara göre daha yüksek oranda miyop görüldüğü vurgulanmıştır. ${ }^{23}$ Sun ve ark. (2018) her iki ebeveynin de miyop bulunan çocuklarda miyop kırma kusurunun daha fazla görüldügünü belirtmiştir. ${ }^{24}$ Miyop sorununun k1z öğrencilerde erkek öğrencilere göre daha hızlı bir oranda artış gösterdiği saptanmıștır. ${ }^{25}$ K1z öğrencilerde $(\% 20,3)$ miyop siklığının erkek $(\% 15,9)$ ögrrencilere göre anlamlı düzeyde daha yüksek olduğu görülmüştür. ${ }^{8}$ (Tablo 1). Rose ve ark. (2008) yaptı̆̆ çalışmada kız çocuklarda miyop sıklığının erkeklere göre daha yüksek olduğunu saptamıştır. ${ }^{22}$ French ve ark. (2013)'nın çalışma sonuçlarına göre kız öğrencilerin erkek öğrencilere göre daha fazla miyop sebebi olan aktivitelere zaman ayırdı $\breve{g} 1$ saptanmıștır. ${ }^{25}$ Açık havada geçirilen sürenin azalmasının miyop oranını arttıran bir etkiye sahip olduğu bulunmuştur. Haftalık ortalama $11,65 \pm 6,97$ saat aç1k havada vakit geçiren çocuklara göre haftalık ortalama 7,98 $\pm 6,54$ saat açık havada vakit geçirenlerin gelecekte miyop sorunu yaşama riskinin daha fazla olduğu saptanmıştır (O.R:0.91, Cl:\%95). ${ }^{20}$ (Tablo 1). Dharani ve ark. (2012)'nın çalışmasına göre haftalık açık havada geçirilen sürenin miyop sorunu üzerinde etkisi

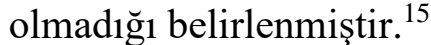


Tablo 1. Göz Sağlığı ile İlgili Araştırmalar

\begin{tabular}{|c|c|c|c|c|c|c|}
\hline Yazar & $\begin{array}{l}\text { Tari } \\
\text { h }\end{array}$ & Amaç & $\begin{array}{c}\text { Araştırmanın } \\
\text { Yeri ve } \\
\text { Örneklemi } \\
\end{array}$ & Yöntem & Bulgular & Sonuç \\
\hline $\begin{array}{l}\text { Khader } \\
\text { ve ark. }\end{array}$ & 2006 & $\begin{array}{l}\text { Okul } \\
\text { çocuklarınd } \\
\text { a miyopi } \\
\text { sıklığ1 ve } \\
\text { risk } \\
\text { faktörlerini } \\
\text { belirlemek }\end{array}$ & $\begin{array}{l}\text { Ürdün'de 12-17 } \\
\text { yaş arası } 1777 \\
\text { (1081 erkek, } \\
696 \text { k1z) çocuk } \\
\text { üzerinde } \\
\text { yürütülmüştür. }\end{array}$ & $\begin{array}{l}\text { Kesitsel tipte } \\
\text { bir çalışmadır. } \\
\text { Sekiz farklı } \\
\text { bölgede } \\
\text { yaşayan } \\
\text { çocuklara } \\
\text { anket } \\
\text { uygulanmıştır }\end{array}$ & $\begin{array}{l}\text { Miyopi yaşın } \\
\text { artmasıyla } \\
\text { anlamlı bir } \\
\text { ilişkiye sahip } \\
\text { bulunmuştur } \\
\text { (14 yaş \% } 20.6 \\
\text { miyop, daha } \\
\text { genç yaş } \\
\text { grubunda \%7.8 } \\
\text { miyop). Her iki } \\
\text { ebeveyninde } \\
\text { miyop sorunu } \\
\text { olanlarda } \\
\text { miyopi sıklığ } 1 \\
\text { \%43.2, } \\
\text { ailesinde } \\
\text { miyop sorunu } \\
\text { olamayanlarda } \\
\text { bu oran \%8.7 } \\
\text { olarak } \\
\text { saptanmıştır. }\end{array}$ & $\begin{array}{l}\text { Miyop ile cinsiyet, yaş } \\
\text { ve yakın çalışma } \\
\text { davranışlarının ilişkili } \\
\text { olduğu belirlenmiştir. }\end{array}$ \\
\hline $\begin{array}{l}\text { Jones } \\
\text { ve ark. }\end{array}$ & 2007 & $\begin{array}{l}\text { Çocuklarda } \\
\text { miyop } \\
\text { gelişme } \\
\text { riskinin } \\
\text { ailesel } \\
\text { miyop } \\
\text { öyküsü ve } \\
\text { görme } \\
\text { aktiviteleriyl } \\
\text { e olan } \\
\text { ilişkisini } \\
\text { incelemek. }\end{array}$ & $\begin{array}{l}\text { Kaliforniya'da } \\
\text { 3. sınıfta (8-9 } \\
\text { yaş) öğrenim } \\
\text { gören } 1038 \text { okul } \\
\text { çağı çocuk } \\
\text { araştırma } \\
\text { grubunu } \\
\text { oluşturmuştur }\end{array}$ & $\begin{array}{l}\text { 3. sınıfta } \\
\text { öğrenim gören } \\
1038 \text { çocuk } \\
\text { uzun izlemli } \\
\text { (longitudinal) } \\
\text { olarak } \\
\text { izlenmiştir. } \\
\text { Çocuklar } \\
\text { muayene } \\
\text { edilmiş ve } \\
\text { ailelere anket } \\
\text { uygulanmıştır. }\end{array}$ & $\begin{array}{l}\text { Miyop tanısı } \\
\text { almayan } \\
\text { çocukların } \\
\text { haftalık } \\
\text { ortalama } \\
11.65 \pm 6.97 \\
\text { saat sporsal ve } \\
\text { açık havada } \\
\text { aktivite } \\
\text { yaparken } \\
\text { miyop tanısı } \\
\text { alan çocukların } \\
7.98 \pm 6.54 \text { saat } \\
\text { aktivite yaptığ1 } \\
\text { saptanmıştır. }\end{array}$ & $\begin{array}{l}\text { Sporsal ve açık hava } \\
\text { aktivitelerinin,ebeveynl } \\
\text { erin miyop öyküsü ve } \\
\text { miyop problemine } \\
\text { sahip ebeveyn sayısının } \\
\text { çocuklarda miyop } \\
\text { gelişiminde etkili } \\
\text { faktörler olduğu } \\
\text { saptanmıştır. }\end{array}$ \\
\hline $\begin{array}{l}\text { Rose ve } \\
\text { ark. }\end{array}$ & 2008 & $\begin{array}{l}\text { Okul çağı } \\
\text { çocuklarda } \\
\text { miyop ile } \\
\text { açık hava } \\
\text { aktivitesi ve } \\
\text { yakın } \\
\text { çalışma } \\
\text { özelliklerini } \\
\text { n ilişkisini } \\
\text { incelemektir } \\
\text {. }\end{array}$ & $\begin{array}{l}\text { Sidney'de } 1 . \\
\text { sinıftan } 765 \\
\text { öğrenci, } 7 . \\
\text { sınıftan } 2367 \\
\text { öğrenci olmak } \\
\text { üzere iki farklı } \\
\text { yaş grubu dahil } \\
\text { edilmiştir. }\end{array}$ & $\begin{array}{l}\text { İki yıl izlem } \\
\text { süreci } \\
\text { kapsamında } \\
\text { göz } \\
\text { muayenesi, } \\
\text { anket formu } \\
\text { uygulamasınd } \\
\text { an oluşmuştur. }\end{array}$ & $\begin{array}{l}\text { Cinsiyet (kı), } \\
\text { etnik köken } \\
\text { (Avrupa), } \\
\text { ailesel miyop } \\
\text { öyküsü, yakın } \\
\text { çalışma } \\
\text { davranışı, anne } \\
\text { baba eğitimi, } \\
\text { mesleği, açık } \\
\text { havada } \\
\text { harcanan } \\
\text { zaman ve } \\
\text { miyopi } \\
\text { arasında her iki } \\
\text { yaş grubunda } \\
\text { anlamlı bir } \\
\text { ilişkiye sahip } \\
\text { bulunmuştur. }\end{array}$ & $\begin{array}{l}\text { Açık hava etkinliğinin } \\
\text { arttırılmasının miyopi } \\
\text { üzerinde koruyucu bir } \\
\text { halk sağlığı önlemi } \\
\text { olduğu saptanmıştır. }\end{array}$ \\
\hline
\end{tabular}


Tablo 1. Göz Sağlığı ile İlgili Araştırmalar (Devamı)

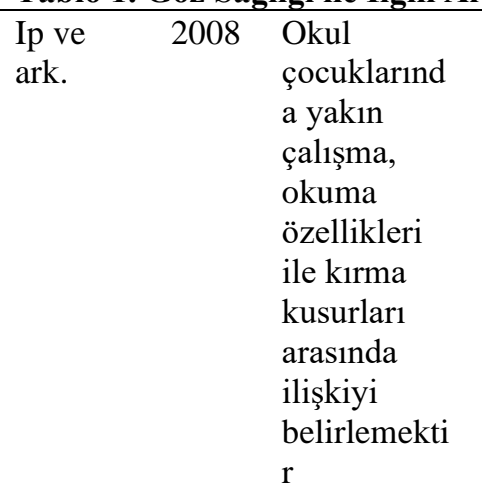

\begin{tabular}{|c|c|c|}
\hline $\begin{array}{l}\text { Dharani } \\
\text { ve ark. }\end{array}$ & 2012 & $\begin{array}{l}\text { Okul } \\
\text { çocuklarınd } \\
\text { a miyopta } \\
\text { belirleyici } \\
\text { olan açık } \\
\text { hava aktivite } \\
\text { zamanı ve } \\
\text { 1şık düzeyini } \\
\text { karşılaştırm } \\
\text { ak. }\end{array}$ \\
\hline
\end{tabular}

Singapur'da 6- Randomize

12 yaş arası 117 kontrollü bir çocuk araştırmanın örneklemini oluştur muştur.

Sidney'in

metropol

bölgesinde yer

alan okuldaki

12-14 yaş arası

2353 öğrenci

oluşturmuştur.

Uzun izlemli

deneysel bir

çalışmadır.

Öğrencilere

ayrıntılı göz

muayenesi, 65

soruluk bir

anket ve

ebeveynlere

de 173 soruluk

bir anket

uygulanmıştır.

çalışmadir.

Ebeveyn

rehberliğinde

tüm çocuklar

her haftanın 7

günü

süresince bir

1şı ölçer

takmıştır.

$\begin{array}{ll}\text { Jones } & 2012 \\ \text { ve ark } & \text { Miyopinin } \\ & \text { ilerlemesind } \\ & \text { e çeşitli } \\ & \text { görsel } \\ & \text { aktivitelerin } \\ & \text { ve açık } \\ & \text { havada } \\ & \text { zaman } \\ & \text { geçirmenin } \\ & \text { ilişkisini } \\ & \text { incelemektir }\end{array}$

$\begin{array}{ll}\text { Guo ve } 2013 & \text { Okul } \\ \text { ark. } & \text { çocuklarınd } \\ & \text { aki } \\ & \text { miyopinin iç } \\ & \text { ve diş } \\ & \text { mekanlarda } \\ & \text { ki aktivite } \\ & \text { ile ilişkisini } \\ & \text { belirlemekti } \\ & \text { r }\end{array}$

Ohio'da 6-14

yaş arası 835

miyop problemi

olan çocuk

araştırma

grubunu

oluşturmuştur.
Deneysel bir

çalışmadır.

Öğrencilerin

ailelerine

çocuklarının

okul yilı

boyunca

yaptığ 1

aktiviteler ve

tıbbi öykü,

göz

problemine

ilişkin soruları

içeren anket

uygulanmıştır.

Pekin'de 5-13 Uzun izlemli

yaş arası 681

öğrenci ile

yürütülmüştür.

Kirsal ve kentsel

olarak iki bölge

dahil edilmiştir.

\section{okul bazlı bir}

araştırmadır.

Aileler ve

çocuklarla iç

ve diş mekan

aktivitelerine

ilişkin

yüzyüze

görüşme

yapılmıştır.

Çocukların 1

yıl ara ile

gözleri

muayene

edilmiștir.

\section{Erkeklerde Okuma mesafesi, etnik \\ (\%64.1) kızlara köken, cinsiyet, ailesel göre (\%47), \\ Avrupa Kafkas \\ kökenli \\ olanlarda}

(\%81.3) diğer

etnik kökenlere

göre $(\% 55.8)$

anlamlı

düzeyde kırma

kusuru oranı

daha yüksek

bulunmuştur.

Katılımciların

\%55.6'sinda

miyop sorunu

mevcuttur.Günl

ük açık havada

geçirilen

sürenin $(7.91$

saat/haftalık)

ve 1 ş1k

düzeyinin (9.81

saat/haftalık

maruz kalma)

anlamlı bir

farka sahip

olduğu tespit

edilmiştir.

\section{Okuma}

Saatinin

Miyopi

ilerlemesinde

küçük bir

farkla (0.13D)

anlamlı olduğu

saptanmıştır.

Miyop ile günlük açık

havada geçirilen zaman

ve yüksek $1 s ̧ 1 k$

yoğunluğu arasında bir

ilişki saptanmamıştır.

Miyopinin

ilerlemesinde bu yaş

grubunda açık hava

aktivitesinin etkili

olmadığ1 saptanmıştır.

Miyop kırma

kusurunun

daha az açık

havada aktivite

yapanlarda

daha fazla

olduğu

saptanmıştır
Miyopi artışında açık havada daha az zaman harcanmasinın ve kapalı alanlarda geçirilen sürenin artmasının 1 yıllık izlem sürecinde etkili faktörler olduğu ortaya konmuştur. 
Tablo 1. Göz Sağlığı ile İlgili Araştırmalar (Devamı)

\begin{tabular}{|c|c|c|c|c|c|c|}
\hline $\begin{array}{l}\text { Scheim } \\
\text { an ve } \\
\text { ark. }\end{array}$ & 2014 & $\begin{array}{l}\text { Miyopinin } \\
\text { diş mekan } \\
\text { ve yakın } \\
\text { çalışma } \\
\text { aktiviteleri } \\
\text { ile ilişkisini } \\
\text { belirlemekti } \\
\text { r. }\end{array}$ & $\begin{array}{l}\text { Amerika'da 6- } \\
11 \text { yaş arası } 469 \\
\text { çocuk üzerinde } \\
\text { yürütülmüştür }\end{array}$ & $\begin{array}{l}5 \text { yıl izlem } \\
\text { süreli } \\
\text { deneysel bir } \\
\text { çalışmadır. } \\
\text { Aileler } \\
\text { çocuklarının } \\
\text { haftada } 3 \text { gün } \\
\text { açık hava ve } \\
\text { yakın çalışma } \\
\text { faaliyetlerini } \\
\text { kaydetmiştir. }\end{array}$ & $\begin{array}{l}\text { Miyop derecesi } \\
\text { artanların yakın } \\
\text { çalışma } \\
\text { aktivitelerine } \\
\text { daha fazla } \\
\text { zaman ayırdı̆̆ı } 1 \\
\text { gözlenmiştir. }\end{array}$ & $\begin{array}{l}\text { Çocukluk çağında kapı } \\
\text { dışarı aktivitenin } \\
\text { miyopinin artışıyla bir } \\
\text { ilişkisi olmadığ1 } \\
\text { saptanmıştır. Daha } \\
\text { erken çocukluk } \\
\text { döneminde daha az } \\
\text { yakın çalışma } \\
\text { aktivitelerine harcanan } \\
\text { zamanın miyopi } \\
\text { derecesi ile ilişkili } \\
\text { olabileceği } \\
\text { belirlenmiştir. }\end{array}$ \\
\hline $\begin{array}{l}\text { Wu ve } \\
\text { ark. }\end{array}$ & 2013 & $\begin{array}{l}\text { Okul } \\
\text { çocuklarınd } \\
\text { a açık hava } \\
\text { aktivitesinin } \\
\text { miyop } \\
\text { üzerine } \\
\text { etkisini } \\
\text { araştırmaktır } \\
\text {. }\end{array}$ & $\begin{array}{l}\text { Tayvan'da 7-11 } \\
\text { yaş arası } 333 \\
\text { deney grubu, } \\
238 \text { kontrol } \\
\text { grubu olmak } \\
\text { üzere toplam } \\
571 \text { ögrenci } \\
\text { oluşturmuştur. }\end{array}$ & $\begin{array}{l}\text { Prospektif bir } \\
\text { müdahale } \\
\text { araştırmasıdır. } \\
\text { Bir okul deney } \\
\text { grubunu diğer } \\
\text { okullardan } \\
\text { gelen } \\
\text { öğrenciler } \\
\text { kontrol } \\
\text { grubunu } \\
\text { oluşturmuştur. } \\
\text { Deney grubu } \\
\text { öğrencilere } \\
\text { teneffüslerde } \\
\text { açık hava } \\
\text { etkinliklerini } \\
\text { teşvik eden bir } \\
\text { program } \\
\text { uygulanmıştır. } \\
\text { Kontrol grubu } \\
\text { okullarda özel } \\
\text { bir program } \\
\text { uygulanmamış } \\
\text { tır }\end{array}$ & $\begin{array}{l}\text { Deney grubu } \\
\text { öğrencilerde } \\
\text { miyopi } \\
\text { başlangicı } \\
\text { olanlar kontrol } \\
\text { grubu } \\
\text { öğrencilere } \\
\text { göre anlamlı } \\
\text { düzeyde daha } \\
\text { düşük bir } \\
\text { oranda } \\
\text { bulunmuştur } \\
\text { (p<0.001,\% } 8.1 \\
\text { vs. \%17.65). } \\
\text { Deney } \\
\text { grubunda } \\
\text { miyop } \\
\text { derecesinde } \\
\text { artış kontrol } \\
\text { grubuna göre } \\
\text { daha düşük } \\
\text { olarak } \\
\text { saptanmıştır. }\end{array}$ & $\begin{array}{l}\text { Okulda, teneffüslerde } \\
\text { arttırılan açık hava } \\
\text { etkinliklerinin } \\
\text { miyopinin } \\
\text { başlamasında ve } \\
\text { ilerlemesinde önemli } \\
\text { bir etkiye sahip olduğu } \\
\text { saptanmıştır. }\end{array}$ \\
\hline $\begin{array}{l}\text { French } \\
\text { ve ark. }\end{array}$ & 2013 & $\begin{array}{l}\text { Miyop ile } \\
\text { ilişkili } \\
\text { aktiviteleri } \\
\text { (fazla süre } \\
\text { yakın } \\
\text { çalışma ve } \\
\text { azalmış açık } \\
\text { hava } \\
\text { aktivitesi) } \\
\text { İncelemektir } \\
\text {. }\end{array}$ & $\begin{array}{l}\text { Avustralya'da } 6 \\
\text { ve } 12 \text { yaşında } \\
\text { yer alan } 6 \text { yaş } \\
\text { grubunda } 1765 \\
\text { kişi, } 12 \text { yaş } \\
\text { grubunda } 2353 \\
\text { kişi ile } \\
\text { yürütülmüştür. } \\
\text { Sidney'in } \\
\text { metropolünde } \\
\text { yer alan } 34 \text { 'ü } \\
\text { ilkokul, } 21 \text { 'i } \\
\text { ortaokul toplam } \\
55 \text { okulda } \\
\text { gerçekleştirilmiş } \\
\text { tir. }\end{array}$ & $\begin{array}{l}\text { Uzun izlemli } \\
\text { bir kohort } \\
\text { çalışmasıdır. } \\
\text { Araştırmanın } \\
\text { ilk aşaması } \\
\text { 2003-2005 } \\
\text { yılları arası } \\
\text { Sidney Miyop } \\
\text { çalışma grubu } \\
\text { tarafından } \\
\text { ikinci aşaması } \\
\text { 2009-2011 } \\
\text { yılları arası } \\
\text { Sidney } \\
\text { adölesan göz } \\
\text { çalışma grubu } \\
\text { tarafından } \\
\text { yürütülmüştür. }\end{array}$ & $\begin{array}{l}\text { Doğu Asya } \\
\text { kökenli } \\
\text { çocuklarda (ilk } \\
\text { aşama \%47.3, } \\
\text { ikinci aşama } \\
\text { \%8.9) miyop } \\
\text { s1klı̆g Avrupa } \\
\text { Kafkas kökenli } \\
\text { (ilk aşama } \\
\text { \%36.1, ikinci } \\
\text { aşama \%14.7) } \\
\text { çocuklara göre } \\
\text { daha yüksek } \\
\text { bulunmuştur. }\end{array}$ & $\begin{array}{l}\text { Doğu Asya kökenli } \\
\text { çocuklar Avrupa } \\
\text { Kafkas kökenli } \\
\text { çocuklara göre, kız } \\
\text { çocuklar erkek } \\
\text { çocuklara göre daha } \\
\text { fazla miyop sebebi } \\
\text { aktvite yapmaktadır. }\end{array}$ \\
\hline
\end{tabular}


Tablo 1. Göz Sağlığı ile İlgili Araştırmalar (Devamı)

\begin{tabular}{|c|c|c|c|c|c|c|}
\hline $\begin{array}{l}\text { Lim ve } \\
\text { ark. }\end{array}$ & 2014 & $\begin{array}{l}\text { Okul } \\
\text { çocuklarınd } \\
\text { a miyopi ile } \\
\text { ailesel } \\
\text { miyopi } \\
\text { öyküsü } \\
\text { arasındaki } \\
\text { ilişkiyi } \\
\text { incelemektir }\end{array}$ & $\begin{array}{l}\text { Çin'de 6-18 yaş } \\
\text { arası 15,316 } \\
\text { okul çocuğu } \\
\text { araştırmanın } \\
\text { örneklemini } \\
\text { oluşturmuştur. }\end{array}$ & $\begin{array}{l}\text { Ailesel } \\
\text { özellikler, } \\
\text { yakın çalışma } \\
\text { davranışları, } \\
\text { sporsal } \\
\text { faaliyetler, } \\
\text { beslenme } \\
\text { özellikleri } \\
\text { anket } \\
\text { aracılığıyla } \\
\text { belirlenmiştir. } \\
\text { Göz } \\
\text { muayenesi } \\
\text { yapılmıştır. }\end{array}$ & $\begin{array}{l}\text { Ailesinde bir } \\
\text { ebeveyninde } \\
\text { miyop olan } \\
\text { çocukların } \\
\text { \%59.62'sinde, } \\
\text { her iki } \\
\text { ebeveyninde } \\
\text { miyop } \\
\text { olanlarda } \\
\text { \%64.42, } \\
\text { oranında } \\
\text { anlamlı bir } \\
\text { ilişkiyle miyop } \\
\text { problemine } \\
\text { sahip olduğu } \\
\text { belirlenmiştir. }\end{array}$ & $\begin{array}{l}\text { Ailesel öykünün } \\
\text { çocuklarda görülen } \\
\text { miyopi üzerinde etkili } \\
\text { olduğu saptanmıştır. }\end{array}$ \\
\hline $\begin{array}{l}\text { Parssine } \\
\text { n ve } \\
\text { ark. }\end{array}$ & 2014 & $\begin{array}{l}\text { Miyop } \\
\text { ilerlemesini } \\
\text { ve } \\
\text { ilerlemesiyl } \\
\text { e ilişkili } \\
\text { faktörleri } \\
\text { incelemektir } \\
\text {. }\end{array}$ & $\begin{array}{l}\text { Finlandiya'da } \\
8.7-12.8 \text { yaş } \\
\text { arası } 240 \text { miyop } \\
\text { sorunu olan okul } \\
\text { çocuğu ile } \\
\text { yürütülmüştür }\end{array}$ & $\begin{array}{l}\text { Uzun izlemli } \\
\text { bir deneysel } \\
\text { araştırmadır. } \\
\text { Açı hava } \\
\text { aktiviteleri, } \\
\text { okuma } \\
\text { saatleri, } \\
\text { televizyon } \\
\text { izleme saatleri } \\
\text { gibi soruları } \\
\text { içeren soru } \\
\text { formu } \\
\text { uygulanmıştır. }\end{array}$ & $\begin{array}{l}\text { Kadınlarda } \\
\text { miyopi } \\
\text { erkeklere göre } \\
\text { daha hızlı } \\
\text { ilerlemiştir } \\
\text { (p<0.001). } \\
\text { Ailesinde } \\
\text { miyop } \\
\text { olanlarda } \\
\text { miyop daha } \\
\text { hizlı bir } \\
\text { ilerleme } \\
\text { göstermiştir } \\
\text { (p:0.022). } \\
\text { Günlük okuma } \\
\text { süresi artışı } \\
\text { miyop üzerinde } \\
\text { etkili } \\
\text { bulunmuştur }\end{array}$ & $\begin{array}{l}\text { Ailesel öykünün } \\
\text { çocuklarda görülen } \\
\text { miyopi üzerinde etkili } \\
\text { olduğu saptanmıştır. } \\
\text { Okuma süresi, kapalı } \\
\text { alanda vakit geçirme } \\
\text { çocukluk miyopisi ile } \\
\text { ilişkili bulunmuştur. }\end{array}$ \\
\hline $\begin{array}{l}\text { Saxena } \\
\text { ve ark. }\end{array}$ & 2015 & $\begin{array}{l}\text { Kentte } \\
\text { yaşayan } \\
\text { okul } \\
\text { çocuklarınd } \\
\text { a miyopi } \\
\text { prevalansı } \\
\text { ve ilişkili } \\
\text { risk } \\
\text { faktörlerini } \\
\text { tanımlamakt } \\
\text { 1r }\end{array}$ & $\begin{array}{l}\text { Hindistan'ın } \\
\text { başkenti } \\
\text { Delhi'de } 9884 \\
\text { okul çocuğu } \\
\text { araştırma } \\
\text { grubunu } \\
\text { oluşturmuştur. }\end{array}$ & $\begin{array}{l}\text { Kesitsel } \\
\text { tiptedir. } \\
\text { Snellen eşeli } \\
\text { ile görme } \\
\text { taraması } \\
\text { yapılmış ve } \\
\text { anket ile } \\
\text { sosyodemogra } \\
\text { fik veriler } \\
\text { toplanmıştır. }\end{array}$ & $\begin{array}{l}\text { Miyopi } \\
\text { prevalansı } \\
\text { \%13.1'dir. } \\
\text { Özel okulda } \\
\text { okuyanlarda } \\
\text { (p<0.001), } \\
\text { Aile öyküsüne } \\
\text { sahip olanlarda } \\
\text { (p<0.001), } \\
\text { yüksek sosyo } \\
\text { ekonomik } \\
\text { düzeyde } \\
\text { (p=0.037), } \\
\text { 5saat ve üzeri } \\
\text { dersçalışma } \\
\text { davranış1 } \\
\text { olanlarda, } \\
\text { günde } 2 \text { saatten } \\
\text { fazla } \\
\text { televizyon } \\
\text { izleyenlerde } \\
\text { miyopi ile } \\
\text { anlamlı bir } \\
\text { ilişki } \\
\text { bulunmuștur. }\end{array}$ & $\begin{array}{l}\text { Miyopi gelişiminde } \\
\text { aile öyküsü, okul türü, } \\
\text { sosyoekonomik düzey, } \\
\text { ders çalışma ve } \\
\text { televizyo izleme } \\
\text { saatleri ilşkili faktörler } \\
\text { olarak tanımlanmıştır. }\end{array}$ \\
\hline
\end{tabular}




\begin{tabular}{|c|c|c|c|c|c|}
\hline $\begin{array}{l}\text { Sun ve } 2018 \\
\text { ark. }\end{array}$ & $\begin{array}{l}\text { Doğu } \\
\text { Çin'de okul } \\
\text { çağı } \\
\text { çocuklarda } \\
\text { miyopi } \\
\text { prevalansı } \\
\text { ve ilişkili } \\
\text { risk } \\
\text { faktörlerini } \\
\text { tanımlamakt } \\
\text { 1r. }\end{array}$ & $\begin{array}{l}\text { Doğu Çin'de } \\
3753 \text { (10-15 } \\
\text { yaş) okul çağ1 } \\
\text { çocuk ile } \\
\text { yürütülmüştür }\end{array}$ & $\begin{array}{l}\text { Kesitsel } \\
\text { tiptedir. Anket } \\
\text { uygulaması } \\
\text { yapılmıştır. }\end{array}$ & $\begin{array}{l}\text { Yaşın artışı ile } \\
\text { miyopi } \\
\text { arasında } \\
\text { anlamlı bir } \\
\text { ilişki } \\
\text { bulunmuştur } \\
\text { (p<0.001), } \\
\text { Yakın çalışma } \\
\text { aktivitelerine } \\
\text { ayrılan } \\
\text { zamanın } \\
\text { artması ve açık } \\
\text { hava } \\
\text { aktivitelerine } \\
\text { ayrılan } \\
\text { zamanın } \\
\text { azalması } \\
\text { miyopi } \\
\text { görülme } \\
\text { sıklığını } \\
\text { anlamlı } \\
\text { düzeyde } \\
\text { arttırmıştır } \\
\text { p<0.001). }\end{array}$ & $\begin{array}{l}\text { Yaş,açık hava aktivite } \\
\text { süresi, yakın çalışma } \\
\text { aktivite süresi miyop } \\
\text { gelişimi ile ilişkili } \\
\text { faktörler olarak } \\
\text { tanımlanmıştır. }\end{array}$ \\
\hline
\end{tabular}

Günlük olarak üç saatten daha az bir zamanı açık hava aktivitelerine ayıran çocuklarda miyop sorunu artışının açık havada üç saatten daha fazla zaman geçiren çocuklara göre daha yüksek olduğu ortaya çıkmıştır. ${ }^{21}$ Açık havada geçirilen zamanın axial uzunlukta etkili olduğu görülmüştür. Açık havada yeterli zamanı ayırmayan çocuklarda axial uzunluğun açık havada daha fazla zaman geçiren çocuklara göre arttığını saptamıştır. ${ }^{22}$ Açık havada sporsal faaliyetlere daha az zaman (1,87 saat/gün) ayıran çocuklarda bu faaliyetlere daha fazla zaman (4,04 saat/gün) ayıranlara göre miyop daha yüksek oranda görülmüştür. ${ }^{14}$ Scheiman ve ark (2014)'nın yaptıkları çalışmada açık hava etkinliklerine ayrılan zamanın (haftalık 9 saat ve daha az zaman ayıranlar \%60,2, 9 saatin üzerinde zaman ayıranlar \%59,1 miyop ilerlemesinde etkili olmadığ 1 saptanmıştır. ${ }^{19}$ Sun ve ark.(2018) yürüttüğü çalışmada çocuklarda yaşın artması ile açık havada geçirilen sürenin azaldığını, miyop görülme sıklığının arttığını belirlemiştir. ${ }^{24}$

Jones ve ark.(2012)'nın çalışmasında yakın çalışma aktiviteleri ile miyop gelişimi arasında ilişki olmadığ 1 saptanmıştır. ${ }^{16}$ Günlük okuma saatinin üç saat üzerine çıkmasının miyop derecesinin ilerlemesinde etkili olduğu belirlenmiștir (r:0,253, p:0,001). Günlük olarak televizyon karşısında geçirilen vaktin üç saat üzerine çıkması miyop ilerlemesinde etkili bir faktör olduğu görülmüştür $(p=0,065)^{21}$ Televizyon izleme davranışının axial uzunluk üzerinde etkili olduğu saptanmıştır. ${ }^{22}$ Bilgisayar kullanımı, okuma ve yazma gibi yakın mesafe göz aktivitelerinde her fazladan bir saatin miyop riskini \%16-24 arasında arttırdığ1 belirlenmiştir. ${ }^{14}$ Yakın çalıșma aktivitelerine ayrilan zamanın (haftalık 21 saat ve daha az zaman ayıranlar \%63, 21 saatten daha fazla zaman ayıranlar \%56,1) miyop ilerlemesi ile ilişkisi saptanmamıştır. ${ }^{23}$ Saxena ve ark.(2015) günlük 5 saatin üzerinde okuma, ders çalışma faaliyetlerine zaman ayıranlarda, günde 2 saatin üzerinde televizyon izleme, bilgisayarda vakit geçirme, video oynama gibi aktiviteler yapanlarda miyop görülme sıklığının anlamlı düzeyde arttığını tespit etmiştir $(p \leq 0,001) .{ }^{26} \mathrm{Bu}$ çalışmada göz sağlığını etkileyen faktörlerin incelendiği çalışmalar irdelenmiştir. Buna göre yapılan çalışmaların kırma kusurları arasından miyop göz problemi üzerine odaklandığ görülmüştür. Yapılan çalışmalar daha çok 
sorunu olan çocukların ebeveynlerinde miyop

deneysel ve uzun izlemli çalışmalardan oluşmaktadır. ${ }^{12,19-25}$ Çalışmaların sonuçları incelendiğinde miyop göz problemi üzerinde etkili olabileceği düşünülen faktörlerin açık hava aktivitesi, yakın çalışma davranışları, ailesel öykü ve cinsiyet olduğu görülmüştür. Ailede yer alan miyop sorunlu ebeveynin miyop gelişimi üzerine etkisinin incelendiği çalışma sonuçlarına göre; miyop sorunu olmayan çocukların annelerinin yaklaşık \%48'i miyop tanısına sahipken, miyop sorunu olan çocukların annelerinde bu oran \%69 olarak belirlenmiştir. Benzer şekilde miyop sorunu olmayan çocukların babalarının $\% 44$ 'ü miyop tanısına sahip, miyop sorununa sahip çocukların babalarının \%64'ünün miyop sorunu yaşamakta olduğu saptanmıştır. Anne ve babanın miyop sorununa ilişkin sağlik öyküsü çocukların miyop sorunu yaşaması üzerinde etkili faktör olarak görülmüştür. ${ }^{20}$ Aynı zamanda Jones ve ark. (2012)'nın çalışmasında miyop sorunu yaşayan ebeveyn sayısı da miyop üzerinde etkili faktörlerden biri olarak belirlenmiştir. Buna göre hiçbir ebeveyninde miyop sorunu olmayan çocukların gelecekte \%21'i miyop için riskliyken her iki ebeveyninde miyop sorunu olan çocuklarda bu risk \%45 olarak belirgin bir artış göstermektedir. ${ }^{20}$ Miyop sorununun ilerlemesinin incelendiği çalışmada ailesel olarak miyop sorunu öyküsüne sahip olanlarda miyop sorununun ilerleyişi daha hızlı olmuştur. ${ }^{21}$ Guo ve ark. (2013) yaptığı çalışmada annenin miyop öyküsüne sahip olmasının çocuğun axial uzunluğu üzerinde etkili olduğunu belirlemiştir. ${ }^{22}$ Ebeveynlerinde miyop öyküsü bulunmayan çocuklarda miyop \%8,7 oranında görülürken her iki ebeveyninde miyop sorunu olan çocuklarda $\% 43,2$ oranında miyop görüldüğü saptanmıştır. ${ }^{14}$ Ebeveynlerinden en az birinde miyop öyküsü olanların ailesinde miyop sorunu olmayanlara göre daha fazla miyop sorunu yaşadığı belirlenmiştir. ${ }^{25}$ Annenin miyop sorununa sahip olması çocukların gelecekte miyop sorunu yaşamasında \%24 oranında etkili babanın miyop sorununa sahip olmasının çocuğun göz problemi yaşamasında $\% 25$ oranında etkili faktörler olduğu saptanmıştır. ${ }^{18}$ Ip ve ark.(2008) yaptıkları çalışmada en az bir ebeveyninde miyop göz problemi olmayanlara göre anlamlı düzeyde miyop görülme sıklığının daha fazla olduğunu belirlemişlerdir $(\mathrm{Cl}, 1,9-3,8) .{ }^{21}$ Yürütülen çalışmaların sonuçlarının büyük oranı ailesel miyop öyküsünün miyop gelişimi ve ilerlemesinde etkili faktörler olduğu ortaya konmuştur. Cinsiyet faktörünün incelendiği çalışma sonuçlarına göre; kız öğrencilerde miyop sorununun erkek öğrencilere göre daha yüksek oranda görüldüğü ve daha hızlı ilerlediği ortaya çıkmıştır. ${ }^{14,21,25}$ Açık hava aktivitesinin etkisine ilişkin çalışmalar incelendiğinde; günlük olarak üç saatten daha az bir zamanı açık hava aktivitelerine ayıran çocuklarda miyop sorunu artışının açık havada üç saatten daha fazla zaman geçiren çocuklara göre daha yüksek olduğu ortaya çıkmıştır. ${ }^{21}$ Açık havada geçirilen sürenin miyop ilerlemesinde etkili olduğu belirlenmiştir. ${ }^{14,22,25}$ Buna karşın açık hava etkinliklerinin miyop üzerinde etkili olmadığına ilişkin az da olsa çalışma sonuçları bulunmaktadır. ${ }^{19,23}$ Günlük okuma saatinin üç saat üzerine çıkmasının miyop derecesinin ilerlemesinde etkili olduğu belirlenmiştir. Günlük olarak televizyon karşısında geçirilen vaktin üç saat üzerine çıkması miyop ilerlemesinde etkili bir faktör olduğu görülmüştür. ${ }^{21}$ Bilgisayar kullanımı, okuma ve yazma gibi yakın mesafe göz aktivitelerinde her fazladan bir saatin miyop riskini \%16-24 arasında arttırdı $\breve{g} 1$ belirlenmiştir. ${ }^{14}$ Kitap okuma mesafesi 30 cm.'den daha az olan çocuklarda hipermetrop sorunu anlamlı düzeyde daha yüksek oranda bulunmuştur. ${ }^{26}$ Yakın çalışma davranışının miyop üzerinde etkili olmadığı araştırma sonuçları da literatürde yer almaktadır. ${ }^{20,23}$ Saxena ve ark.(2015) yaptıkları çalışmada günlük 5 saatin üzerinde okuma, ders çalışma faaliyetlerine zaman ayıranlarda, günde 2 saatin üzerinde televizyon izleme, bilgisayarda vakit geçirme, video oynama gibi aktiviteler yapanlarda miyop görülme sıklığının anlamlı düzeyde arttığını tespit etmiştir. ${ }^{23}$ Çocuklarda göz sağlığını etkileyen faktörleri inceleyen çalışmalara bakıldığında; kırma kusurları arasında en sık olarak görülen miyop göz problemi ve etkileyen faktörler üzerine odaklanmaktadır 


\section{SONUÇ VE ÖNERILER}

$\mathrm{Bu}$ sistematik derlemede okul çağ çocuklarında miyop ile ilişkili faktörleri inceleyen çalışmalar gözden geçirilmiştir. Literatürde sadece İngiliz dilinde yayınlanmış çalışmaların olduğu dikkati çekmiştir. Miyop gelişiminde ve ilerlemesinde ailesel öyküde miyop varlığının, kız cinsiyet olmanın, fazla süre yakın çalışma aktivitesi ve yetersiz açık hava aktivitesinin miyop gelişiminde ve ilerlemesinde rol oynadığ1 görülmüştür. Miyop görme probleminin çocukluk çağında gelişiminin önlenmesinde risk faktörlerini inceleyen araştırmaların yapılması ve toplumu bilinçlendirici girişimsel eğitim müdahalesi olan araștırmaların ülkemizde yürütülerek sonuçların literatüre kazandırılması önerilmektedir.

\section{KAYNAKLAR}

1. WHO (2013). Action plan for the prevention of avoidable blindness and visual impairment for 2014-2019 http://www.who.int/blindness/actionplan/en/. Erişim tarihi: 20.05.2017

2. Resnikoff, S, Pascolini, D, Mariotti, SP. (2004). "Global Magnitude of Visual Impairment Caused by Uncorrected Refractive Errors.” Bull World Health Organ, 86 (2), 63-70.

3. Sharma, A, Congdon, N, Patel, M, Gilbert, C. (2012). "Schoolbased approaches to the correction of refractive error in children." Survey of Ophthalmology, 57 (3), 272-283.

4. Çetin, E, Yaman, A, Berk, AT. (2003). "Etiology of Childhood Blindness in Izmir, Turkey." European Journal of Ophthalmology, 14 (6), 531-537.

5. Özden, S, Yıldırım, C, Arıkan, T, Özyurt, C, Kıldacı, B. (1999) "0-6 Yas Arası Göz Taramasında Birinci Basamak Sağlık Örgütlerinin Aktive Edilmesi: Ön Çalışma İlk Sonuçlar." Medical Network Oftalmoloji, 6 (2), 160-164.

6. Yıldız, ZO, Erdoğan, H, Toker, Mİ, Arıcı, MK, Topalkara, A, Kal, A. (2002). "Anasınıfi çocuklarında ambliyopi prevalansı." Medical Network Oftalmoloji, 9 (3),295-297.

7. Toygar, O, Öğüt, MS, Kazokoğlu, H. (2003). “İstanbul'da İlköğretim Çağı Çocuklarında Yapılan Göz Taraması Sonuçları.” Turk J Ophthalmol, 33 (1), 585-591.

8. Polat, SA, Akyol, N. (2003). "İlköğretim 2. Sinıf Öğrencilerinde Ambliyopi ve Alerjik Göz Hastalıkları Sıklı̆̆ı.” T Klin Tıp Bilimleri, 23 (1), 213-219.

9. Jones, LA, Sinnott, LT, Mutti, DO, Mitchell, GL, Moeschberger, ML, Zadnik, K. (2007). "Parental History of Myopia, Sports and Outdoor Activities, and Future Myopia." Investigative Ophthalmology \& Visual Science, 48 (8), 3524-3532.

10. Khader, YS, Batayha, WQ, Abdul-Aziz, SMI, Al-Shiekh-Khalil, MI. (2006). "Prevalence and Risk Indicators of Myopia Among School Children in Amman, Jordan." Eastern Mediterranean Health Journal, 12 (3/4), 434

11. Young, FA. (1961). "The Effect Of Restricted Visual Space On The Primate Eye." American Journal of Ophthalmology, 52 (5), 799-806.

12. Wallman, J, Turkel, J, Tracatman, J. (1978). "Extreme Myopia Produced By Modest Change İn Early Visual Experience." Science, 201 (4362), 1249-1251.

13. Richler, A, Bear, JC. (1980). "Refraction, Near-work and Education. A Population Study in New Foundland." Acta ophthalmologica, 58 (3), 468-478.

14. Lim, LT, Gong, Y, Ah-kee, EY, Xiao, G, Zhang, X, Yu, S. (2014). "Impact of Parental History of Myopia on the Development of Myopia in Mainland China School-Aged Children." Ophthalmology and Eye Diseases, 6 (1), 31.
15. Dharani, R, Lee, CF, Theng, ZX, Drury, V. B, Ngo, C, Sandar, M, Saw, SM.(2012). "Comparison of Measurements of Time Outdoors and Light Levels as Risk Factors for Myopia in Young Singapore Children.” Eye, 26 (7), 911-918.

16. Jones-Jordan, LA, Sinnott, LT, Cotter, SA, Kleinstein, RN, Manny, RE, Mutti, DO, Zadnik, K. (2012). "Time Outdoors, Visual Activity and Myopia Progression in Juvenile-onset Myopes.” Investigative Ophthalmology \& Visual Science, 53 (11), 7169-7175.

17. Parssinen, O, Kauppinen, M, Viljanen, A. (2014). "The Progression of Myopia from its onset at age 8-12 to Adulthood and the Influence of Heredity and External Factors on Myopic Progression. A 23-year follow-up study.” Acta ophthalmologica, $92(8), 730-739$.

18. Guo, Y, Liu, LJ, Xu, L, Tang, P, Lv, YY, Feng, Y, Jonas, JB (2013). "Myopic Shift and Outdoor Activity among Primary School Children: One-Year Follow-Up Study in Beijing." PloS one , $8(9), 1-8$.

19.Scheiman, M, Zhang, Q, Gwiazda, J, Hyman, L, Harb, E, Weissberg, E, Dias, L. (2014). "Visual Activity And İts Association With Myopia Stabilisation." Ophthalmic and Physiological Optics, 34 (3), 353-361.

20. Wu, PC, Tsai, CL, Wu, HL, Yang, YH, Kuo, HK. (2013). "Outdoor Activity During Class Recess Reduces Myopia Onset And Progression İn School Children.” Ophthalmology, 120 (5), 1080-1085

21. Ip, JM, Saw, SM, Rose, KA, Morgan, IG, Kifley, A, Wang, JJ, Mitchell, P. (2008). "Role of Near Work in Myopia: Findings in a Sample of Australian School Children." Investigative Ophthalmology \& Visual Science, 49 (7), 2903-2910.

22. Rose, KA, Morgan, IG, Ip, J, Kifley, A, Huynh, S, Smith, W, Mitchell, P. (2008). Outdoor Activity Reduces The Prevalence Of Myopia İn Children. Ophthalmology, 115 (8), 1279-1285.

23. Saxena, R, Vashist, P, Tandon, R, Pandey, RM, Bhardawaj, A Menon, V, Mani, K. (2015). "Prevalence Of Myopia And İts Risk Factors İn Urban School Children İn Delhi: The North India Myopia Study (NIM Study)." PLoS One, 10 (2), 1-11.

24. Sun, JT, An, M, Yan, XB, Li, GH, Wang, DB. (2018). "Prevalence And Related Factors For Myopia in School-Aged Children in Qingdao.” Journal of Ophthalmology, 218 (1), 1-6.

25. French, AN, Morgan, IG, Mitchell, P, Rose, KA. (2013). "Patterns Ofmyopigenic Activities With Age, Gender And Ethnicity in Sydney School Children." Ophthalmic and Physiological Optics, 33 (3), 318-328.

26. Saxena, R, Vashist, P, Tandon, R, Pandey, R. M, Bhardawaj, A, Menon, V, Mani, K. (2015). Prevalence of myopia and its risk factors in urban school children in Delhi: the North India Myopia Study (NIM Study). PloS one, 10 (2). 